\title{
Blood metabolite concentrations and postpartum resumption of ovarian cyclicity in Sanga cows
}

\author{
J.K. Damptey ${ }^{1}$, F.Y. Obese ${ }^{1 \#}$, G.S. Aboagye ${ }^{1}$, M. Ayim-Akonor ${ }^{2}$ \& R.A. Ayizanga ${ }^{1}$ \\ ${ }^{1}$ Department of Animal Science, University of Ghana, P.O. Box LG 226, Legon, Ghana \\ ${ }^{2}$ CSIR-Animal Research Institute, P.O.BOX AH 20, Achimota, Ghana
}

(Received 4 July 2013; Accepted 9 January 2014; First published online 29 January 2014)

\begin{abstract}
Copyright resides with the authors in terms of the Creative Commons Attribution 2.5 South African Licence.
See: http://creativecommons.org/licenses/by/2.5/za

Condition of use: The user may copy, distribute, transmit and adapt the work, but must recognise the authors and the South African Journal of Animal Science.
\end{abstract}

\begin{abstract}
An experiment was conducted to investigate the effect of concentrations of certain blood nutrientsensitive metabolites and the resumption of postpartum ovarian cyclicity in 16 Sanga cows (mean BCS 5). Blood samples were taken from cows from weeks 1 to 13 (90 days) postpartum, processed and the plasma progesterone concentration measured to determine the resumption of postpartum ovarian cyclicity. The cows were classified as having resumed ovarian cyclicity when a plasma progesterone concentration of $\geq 1.0$ $\mathrm{ng} / \mathrm{mL}$ was recorded for two consecutive weekly samples. Based on the resumption of ovarian activity, cows were classified as early cycling, late cycling or non-cycling. The plasma glucose, cholesterol, total protein, albumin and globulin concentrations recorded were similar in the early cycling, late cycling and non-cycling cows. The mean blood glucose, cholesterol, total protein, albumin and globulin concentrations were 3.60 $\mathrm{mmol} / \mathrm{L}, 2.47 \mathrm{mmol} / \mathrm{L}, 83.1 \mathrm{~g} / \mathrm{L}, 29.9 \mathrm{~g} / \mathrm{L}$ and $52.9 \mathrm{~g} / \mathrm{L}$, respectively. Plasma urea concentrations in late $(6.57$ $\pm 0.17 \mathrm{mmol} / \mathrm{L})$ and non-cycling $(6.59 \pm 0.17 \mathrm{mmol} / \mathrm{L})$ cows were higher than in the early cycling $(5.99 \pm 0.17$ $\mathrm{mmol} / \mathrm{L}$ ) cows in weeks 1 to 13 postpartum. In addition, the plasma creatinine concentration in the early cycling cows was higher than in late cycling cows (101.8 \pm 1.82 versus $94.0 \pm 1.99 \mathrm{mmol} / \mathrm{L})$. Cows with higher plasma concentrations of urea and lower creatinine concentrations were at risk of delayed resumption of postpartum ovarian cyclicity. Results suggest poor nutritional status, especially energy deficiency, as a major underlying factor suppressing the postpartum resumption of ovarian cyclicity.
\end{abstract}

Keywords: BCS, creatinine, cycling cows, plasma, postpartum, urea

\# Corresponding author: fyobese@yahoo.com

\section{Introduction}

Cattle production in smallholder systems in Ghana is mainly pasture based. The animals are grazed extensively on natural pastures in the open range, with minimal feed supplementation. The pastures are often limiting in quality and quantity. Thus the nutritional requirements of the cattle are barely met, resulting in poor body condition, weight loss, low milk yield and delays in the resumption of ovarian cycles after calving (Okantah et al., 1999; Obese et al., 2010). The low productivity of cattle in these pasture-based extensive grazing systems therefore needs improvement, and this entails an evaluation of their nutritional status. The assessment of the nutritional and health status in cattle can be made by determining certain blood metabolite concentrations (Ndlovu et al., 2007). These metabolite concentrations indicate the extent of the metabolism of energy, proteins and other nutrients in the animals (Pambu-Gollah et al., 2000; Agenas et al., 2006). The changes in the circulating nutrient-sensitive metabolite concentrations are important signals of the metabolic status of the animal and the ovarian function (Lindsay et al., 1993; Wettemann et al., 2003). These metabolites include non-esterified fatty acids (NEFA), $\beta$-hydroxybutyrate (BHB), glucose and cholesterol, which reflect energy status. Other blood metabolites, such as total protein, albumin, globulin, creatinine and urea, then serve as indicators of the protein status. Factors including the physiological status of an animal, breed, nutrition, season and age may affect the concentration of these metabolites in the blood (Ndlovu et al., 2007).

Glucose is the principal source of energy for the life processes of the mammalian cell (Saleh et al., 2011). It is the metabolite providing information for the control of gonadotrophin-releasing hormone (GnRH) 
secretion, as its availability influences tonic and surge modes of luteinizing hormone (LH) secretion, presumably through its effects on GnRH (Diskin et al., 2003). Inadequate availability of utilizable glucose thus reduces the hypothalamic release of $\mathrm{GnRH}$, leading to a decrease in $\mathrm{LH}$ release, and eventually delaying or preventing ovulation (Hess et al., 2005). Lipid mobilization is increased in early lactation, particularly during the negative energy balance state leading to elevations in the blood NEFA and BHB concentrations (Walters et al., 2002). Elevated concentrations of NEFA and BHB have been associated with prolonged postpartum anoestrous intervals in cows (Reist et al., 2000). A decrease in plasma cholesterol concentration, has been reported to result in a reduction in the plasma concentrations of insulin-like growth factor 1(IGF-I) and progesterone and consequently delayed or inhibited ovulation (Maciel et al., 2001). Creatinine, along with blood urea nitrogen concentration, is an excellent indicator of protein metabolism and kidney function (Stockham \& Scott, 2002; Kohn et al., 2005).

The Sanga is an indigenous breed that is widely used for milk and meat production in smallholder cattle production systems in Ghana (Obese et al., 1999) owing to its relatively large size and better milk production, compared with the other indigenous breeds. This breed is exposed to nutritional deficiencies as a result of inadequate grazing and poor quality pastures, mostly lacking in energy and protein. This situation is likely to be aggravated during the early postpartum period when lactational demands are high and concentrations of blood metabolites associated with the nutritional status of the animal may be affected. The nutritional status of cows after calving is especially important in the resumption of ovarian activity postpartum (Shrestha et al., 2005). Information, however, is limited regarding the concentrations of these circulating nutrient-sensitive energy and protein metabolites and their relationship with the resumption of ovarian activity in Sanga cows managed within the pasture-based systems in Ghana. The objectives of this study were to determine the blood concentrations of glucose, cholesterol, total protein, albumin, globulin, urea and creatinine and assess the relationships between the concentrations of these metabolites and resumption of cyclical activity in Sanga cows. The determination of these blood metabolites could then provide an understanding of the impact of nutritional status on reproduction, and thus guide in the development of management strategies for early resumption of ovarian activity, postpartum.

\section{Materials and Methods}

The study was conducted at the Animal Research Institute's Katamanso station located at latitude $05^{\circ}$ $44^{\prime} \mathrm{N}$ and longitude $00^{\circ} 08^{\prime} \mathrm{W}$ in the Accra Plains of Ghana. The area has a bimodal rainfall pattern with the major wet season occurring from April to July and the minor season from September to November. The remaining months constitute the dry period. The annual rainfall and temperatures range from 600 to 1000 $\mathrm{mm}$ and $20^{\circ} \mathrm{C}$ to $34^{\circ} \mathrm{C}$, respectively.

Sixteen multiparous Sanga cows in their first to fifth parity were used in the study. At the start of the experiment, the cows recorded a mean ( \pm S.E.M.) body weight (BW) of $289.4 \pm 10.8 \mathrm{~kg}$ and body condition score $5.0 \pm 0.2$ (on a scale of 1 to 9 ). The animals were housed in an open kraal and allowed to graze from 05:00 to $10: 00$ and 13:00 to $16: 00$ daily, mainly on natural pastures. Panicum maximum, Sporobolus pyramidalis and Vertiveria fulvibarbis generally constituted the dominant grass species in this area. The cows were not supplied with supplementary feed, before or after grazing, and water was provided twice daily. Cows were milked twice a day during the rainy season and once a day during the dry season. Natural mating was practised with bulls running freely with females all year round, and the calves were weaned between 6 and 9 months of age. Animals were treated against ecto-parasites, mainly ticks, fleas and mange mites, using a pour-on acaricide (Flumethrin $1 \% \mathrm{~m} / \mathrm{v}$ ). Treatment against endo-parasites was done using an antihelminth (Albendazole 10\%). Animals were treated against diseases as the need arose and vaccinated against contagious bovine pleuropneumonia once a year. Cows and their calves were weighed monthly and body condition score of cows determined weekly, using the 9-point score $(1=$ very thin and $9=$ obese $)$ (Nicholson \& Butterworth, 1986).

Blood samples were collected weekly from all cows by jugular venipuncture into a $10 \mathrm{~mL}$ heparinised vacutainer tube (BD Vacutainer Systems, Plymouth, UK), from weeks 1 to 13 (90 days) postpartum at 08:00. Blood tubes were placed on ice immediately after collection, and the plasma separated by centrifugation at $1800 \mathrm{~g}$ for $15 \mathrm{~min}$ at $4{ }^{\circ} \mathrm{C}$. The plasma was stored at $-20^{\circ} \mathrm{C}$, until assayed for the progesterone concentration and the nutrient sensitive metabolites. Resumption of postpartum ovarian cyclicity in cows was determined using the plasma progesterone concentration as indicator. Plasma progesterone concentration was measured weekly from weeks 1 to 13 using a progesterone ELISA kit (Gesellschaft für Biochemica und Diagnostica $\mathrm{mbH}$, Wiesbaden, Germany). The cows were classified as having resumed ovarian cyclicity when a plasma progesterone concentration of $\geq 1 \mathrm{ng} / \mathrm{mL}$ was recorded for two consecutive weekly samples (Tamadon et al., 2011). Based on this parameter, cows were classified as early cycling (resumed cyclicity $\leq 45$ days postpartum; $n=6$ ), late cycling (resumed cyclicity 46 - 90 days postpartum; $n=5$ ) or non-cycling (no resumption by 90 days postpartum; $n=5$ ). 
The concentrations of the nutrient-sensitive metabolites were measured using the Vitros 950 Chemistry Systems auto-analyser (Ortho Clinical Diagnostics, UK). Blood glucose was measured based on the method of Trinder (1969), while cholesterol was determined based on the enzymatic method of Allain et al. (1974). The total blood protein concentration was determined based on the biuret reaction (Doumas et al., 1981) and albumin determination on the method of Doumas \& Biggs (1972), while globulin concentration in plasma was computed as the difference between the total protein and albumin concentrations (Mapekula et al., 2011). Urea determinations were based on the method by Sampson et al. (1980), while creatinine determinations were according to the method by Ambrose et al. (1983).

The effects of the blood concentrations of the nutrient-sensitive metabolites (glucose, cholesterol, total protein, albumin, globulin, urea and creatinine) on resumption of ovarian activity were analysed using the repeated measures analysis of variance procedure of the Statistical Analysis System (SAS, 1999). The model included as fixed effects treatment (oestrous cycle groups), time (weekly observations), and treatment $x$ time (oestrous cycle groups $\times$ week) interactions. Where the effects were significant, means were separated using the PDIFF procedure of SAS.

\section{Results}

The body weight and body condition score (BCS) of cows are set out in Table 1. Body weight did not differ significantly in the early cycling, late cycling and non-cycling cows. However, the early cycling cows tended to be heavier than late cycling and the non-cycling cows at the resumption of cyclic activity. Body condition scores were higher $(P<0.05)$ in early and late cycling cows, compared with the non-cycling cows.

Table 1 Body weight and body condition score (BCS) in oestrous cycle groups

\begin{tabular}{|c|c|c|c|c|c|}
\hline \multirow[b]{2}{*}{ Parameters } & \multicolumn{3}{|c|}{ Oestrous cycle groups postpartum (LSM \pm SE) } & \multirow[b]{2}{*}{ Overall Mean } & \multirow[b]{2}{*}{$P$-Value } \\
\hline & $\begin{array}{l}\text { Early cycling } \\
(\leq 45 \text { days }) \\
n=6\end{array}$ & $\begin{array}{l}\text { late cycling } \\
\text { (46-90 days) } \\
n=5\end{array}$ & $\begin{array}{l}\text { non-cycling } \\
\text { (within } 90 \text { days) } \\
n=5\end{array}$ & & \\
\hline Body weight (kg) & $298.8 \pm 2.94$ & $283.5 \pm 2.22$ & $294.3 \pm 1.65$ & $292.2 \pm 2.27$ & 0.954 \\
\hline $\mathrm{BCS}$ & $5.12^{\mathrm{a}} \pm 0.10$ & $5.11^{\mathrm{a}} \pm 0.11$ & $4.69^{b} \pm 0.11$ & $4.97 \pm 0.11$ & 0.005 \\
\hline
\end{tabular}

Table 2 Postpartum plasma nutrient-sensitive metabolic concentrations in early cycling, late cycling and noncycling Sanga cows

\begin{tabular}{|c|c|c|c|c|c|}
\hline \multirow{2}{*}{ Parameters } & \multicolumn{3}{|c|}{$\begin{array}{l}\text { Oestrous cycle groups } \\
\text { (LSM } \pm \text { SE) }\end{array}$} & \multirow{2}{*}{ Overall mean } & \multirow{2}{*}{$P$-value } \\
\hline & $\begin{array}{l}\text { Early cycling } \\
(\leq 45 \text { days })\end{array}$ & $\begin{array}{l}\text { Late cycling } \\
\text { (46-90 days) }\end{array}$ & $\begin{array}{c}\text { Non-cycling } \\
\text { (within 90 days) }\end{array}$ & & \\
\hline Glucose (mmol/L) & $3.61 \pm 0.05$ & $3.59 \pm 0.06$ & $3.59 \pm 0.66$ & 3.60 & 0.973 \\
\hline Cholesterol (mmol/L) & $2.44 \pm 0.11$ & $2.49 \pm 0.12$ & $2.47 \pm 0.12$ & 2.47 & 0.946 \\
\hline Total Protein (g/L) & $84.3 \pm 0.92$ & $83.3 \pm 1.00$ & $81.8 \pm 1.00$ & 83.1 & 0.180 \\
\hline Albumin (g/L) & $30.7 \pm 0.05$ & $29.7 \pm 0.55$ & $29.4 \pm 0.55$ & 29.9 & 0.200 \\
\hline Globulin (g/L) & $53.6 \pm 0.70$ & $53.1 \pm 0.77$ & $52.0 \pm 0.77$ & 52.9 & 0.338 \\
\hline Urea (mmol/L) & $5.99^{b} \pm 0.16$ & $6.57^{a} \pm 0.17$ & $6.59^{a} \pm 0.17$ & 6.38 & 0.016 \\
\hline Creatinine $(\mathrm{mmol} / \mathrm{L})$ & $102^{\mathrm{a}} \pm 1.82$ & $94.0^{b} \pm 1.99$ & $97.4^{\mathrm{ab}} \pm 1.99$ & 97.8 & 0.017 \\
\hline
\end{tabular}

Means within the same row with different superscripts $(a, b)$ are significantly different $(P<0.05)$.

LSM: least squares mean.

Glucose, cholesterol, total protein, albumin and globulin concentrations in the plasma did not differ $(P$ $>0.05$ ) in early cycling, late cycling or non-cycling cows (Table 2; Figure 1 ). The overall mean plasma 
glucose, cholesterol, total protein, albumin and globulin concentrations being $3.60 \mathrm{mmol} / \mathrm{L}, 2.47 \mathrm{mmol} / \mathrm{L}$, $83.1 \mathrm{~g} / \mathrm{L}, 29.9 \mathrm{~g} / \mathrm{L}$ and $52.9 \mathrm{~g} / \mathrm{L}$ for the observation period, respectively.

The plasma concentration of urea in late $(6.57 \pm 0.17 \mathrm{mmol} / \mathrm{L})$ and non-cycling cows $(6.59 \pm 0.17$ $\mathrm{mmol} / \mathrm{L})$ was higher $(P<0.05)$ than in the early cycling cows $(5.99 \pm 0.16 \mathrm{mmol} / \mathrm{L})$ for weeks 1 to 13 postpartum (Table 2). The plasma concentrations of urea tended to decline in the early cycling and late cycling cows from weeks 1 to 7 postpartum, before stabilizing for the rest of the period (Figure 2). For the non-cycling cows, a decline in plasma urea concentration was recorded from weeks 1 to 11 postpartum, before the levels began to increase at week 13 . The plasma creatinine concentration in early cycling cows was higher $(P<0.05)$ than in the late cycling cows $(102 \pm 1.82 \mathrm{vs} .94 .03 \pm 1.99 \mu \mathrm{mol} / \mathrm{L})$, while the non-cycling cows recorded concentrations similar to that of early cycling and late cycling cows (Table 2). Creatinine concentrations in the plasma remained relatively stable from week 1 to week 9 postpartum in early cycling cows. The concentrations tended to decline from week 1 to week 11 postpartum in the non-cycling cows, while it increased from week 1 to week 9 postpartum, before stabilizing in the late cycling cows (Figure 3).

Time (weeks postpartum) had a significant effect on plasma glucose $(P<0.01)$ and urea $(P<0.001)$ concentrations. However, there was no significant effect of the treatment $x$ time interaction on the concentrations in any of the nutrient-sensitive metabolites measured in the trial.



Figure 1 Least squares means ( \pm SE) of plasma glucose concentrations in postpartum Sanga cows.

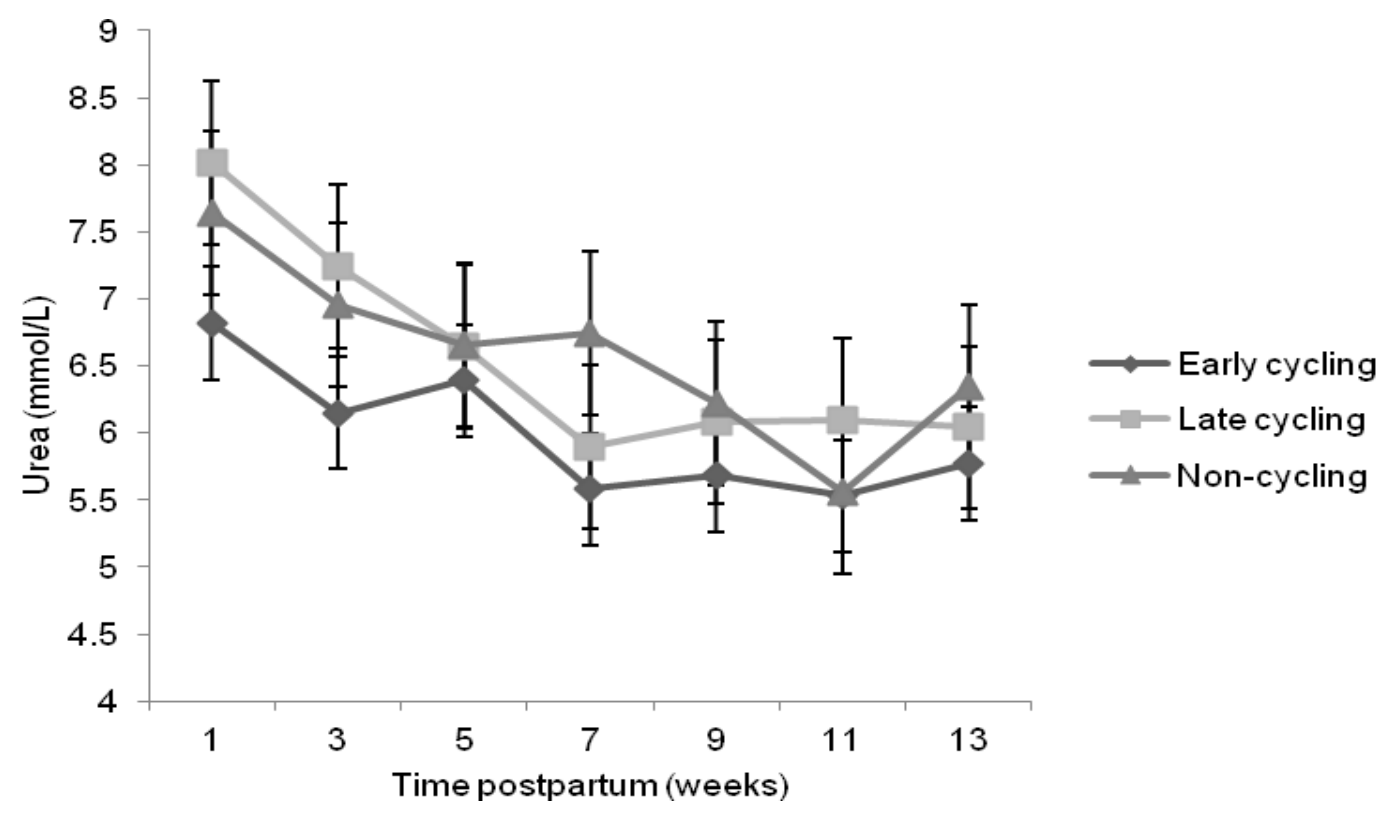

Figure 2 Least squares means ( \pm SE) of plasma urea concentrations in postpartum Sanga cows. 


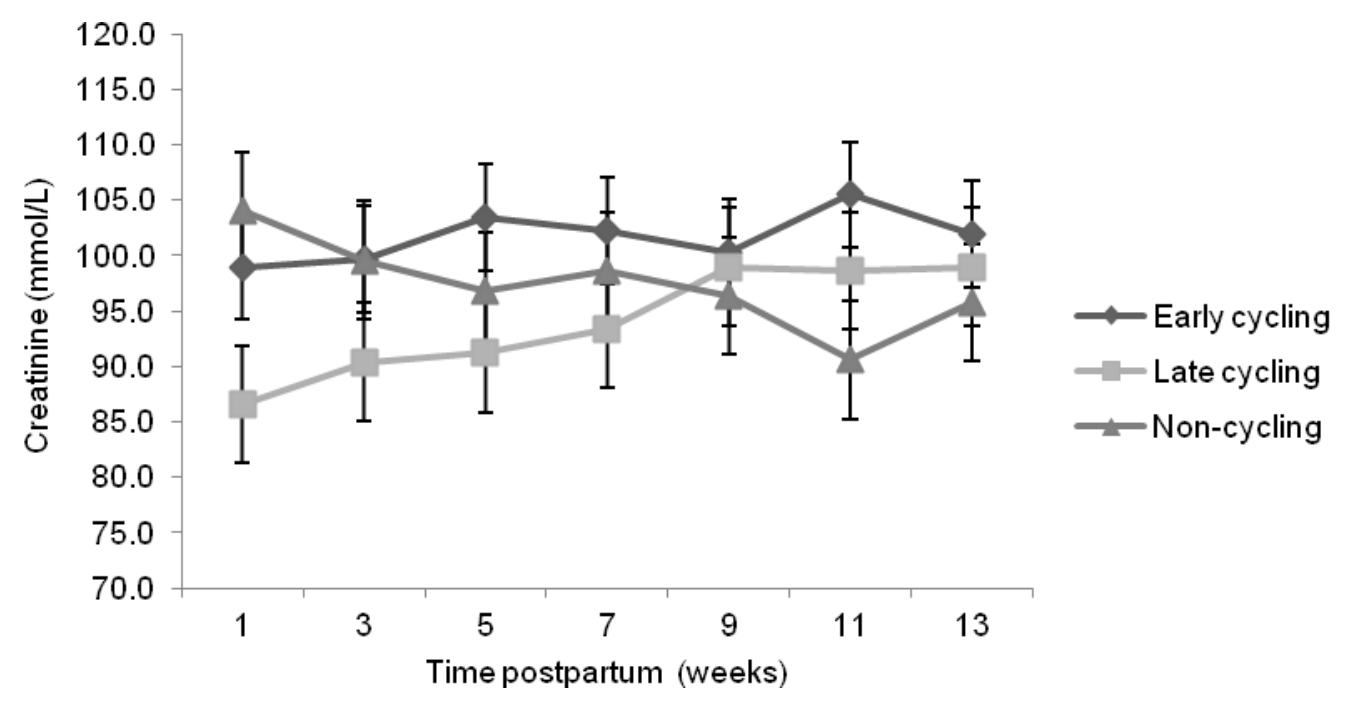

Figure 3 Least squares means ( \pm SE) of plasma creatinine concentrations in postpartum Sanga cows.

\section{Discussion}

This study evaluated the relationship between the concentrations of certain nutrient-sensitive blood metabolites and the resumption of ovarian cyclicity in postpartum Sanga cows. Nutrient availability has been reported to be a major determinant of the postpartum anoestrous period in cattle that graze subtropical pastures. This influences the length of the period to resumption of ovulation after calving in beef and dairy cattle (Ciccioli et al., 2003, Diskin et al., 2003, Samadi et al., 2013). Early cycling and late cycling cows recorded a higher BCS than non- cycling cows. This could be because the higher BCS after calving is an indication of better nutritional status, and may have decreased the risk of suppressed oestrus because of sufficient gonadotrophin production (Montiel \& Ahuja, 2005).

The blood glucose, total cholesterol, total protein, albumin and globulin concentrations did not differ in the early, late or non-cycling cows, indicating no relationship with the resumption of ovarian cyclicity in the Sanga cows studied. The comparable glucose levels in the cycling $(n=11)$ and non-cycling cows $(n=5)$ corroborate an earlier report by Ahmad et al. (2004), who found no significant differences in the serum glucose levels for cycling and non-cycling cows in Pakistan. The overall mean glucose concentration of 3.6 $\mathrm{mmol} / \mathrm{L}$ recorded in the present study was within the normal range of $2.3-4.1 \mathrm{mmol} / \mathrm{L}$ reported for cows (Merck Veterinary Manual, 2010). This may indicate adequate energy supply to the cows (Boonprong et al., 2007). Blood glucose concentration is an important indicator of dietary energy intake (Whitaker et al., 1999). The overall mean blood cholesterol level of $2.47 \mathrm{mmol} / \mathrm{L}$ recorded was within the normal physiological range of 1.6 - $5.0 \mathrm{mmol} / \mathrm{L}$ reported for cows (Merck Veterinary Manual, 2010). Mapiye et al. (2010) recorded an overall mean cholesterol concentration of $3.35 \pm 0.58$ and $3.71 \pm 0.59 \mathrm{mmol} / \mathrm{L}$ for Nguni, and crossbred cattle, respectively, grazing on communal pastures in Eastern Cape, South Africa. The lower value recorded for the Sanga in the present study compared with those recorded by Mapiye et al. (2010) could be due to the low energy requirements and lower degree of adipose tissue breakdown in the Sanga.

The overall mean total protein value of $83.1 \mathrm{~g} / \mathrm{L}$ recorded was within the normal range of $67-85 \mathrm{~g} / \mathrm{L}$ reported for cows (Otto et al., 2000; Merck Veterinary Manual, 2010). Saleh et al. (2011) reported total blood protein concentration values of $76.6 \pm 0.3 \mathrm{~g} / \mathrm{L}$ and $70.6 \pm 0.7 \mathrm{~g} / \mathrm{L}$ for cycling and non-cycling cows, respectively, in Egypt. Albumin concentration in the blood reflects protein status, and the levels decline when there is a protein deficiency (Agenas et al., 2006). The concentration of albumin in the blood has been shown to be significantly correlated with good nutritional condition and hence good BCS in cattle (Kaneko et al., 1997; Coppo, 2004). The overall mean plasma albumin value of $29.9 \mathrm{~g} / \mathrm{L}$ was within the normal range of 25.0 - $39.4 \mathrm{~g} / \mathrm{L}$ reported for cows (Otto et al., 2000; Merck Veterinary Manual, 2010). This suggests that the cows used in the present study were not malnourished. They recorded an overall mean BCS value of 5 , which was medium (moderate) on a 9-point score. The overall mean globulin concentration obtained in the present study was $52.9 \mathrm{~g} / \mathrm{L}$, which was above the normal range (30 - $44.3 \mathrm{~g} / \mathrm{L}$ ) reported for cows (Otto et al., 2000; Merck Veterinary Manual, 2010). The high globulin concentrations recorded for the cows in this study may be as a result of infection (Whitaker et al., 1999). Circulating concentrations of globulin usually give an indication of an animal's immune state and its response to fighting diseases and infections (Kapele et al., 
2008). The high globulin level in the Sanga cows may thus suggest that these cows were prone to infections by ecto- and endo-parasites.

The early cycling cows recorded lower plasma concentrations of urea than late cycling or non-cycling cows in the present study (5.99 vs. 6.57 and $6.59 \mathrm{mmol} / \mathrm{L}$ ). This is in agreement with Ahmad et al. (2004), who also recorded lower urea concentration in cycling than non-cycling cows (11.0 \pm 0.86 versus $12.1 \pm 1.23$ $\mathrm{mmol} / \mathrm{L}$ ). The BCS of late or non-cycling cows were lower compared with that of early cycling cows (Table 1 ). This then suggests that the late and non-cycling cows were in a poorer nutritional status, which could have elicited a situation of energy deficiency, limiting microbial protein synthesis and increasing urea concentrations in the plasma (Murphy et al., 1999). During periods of energy restrictions, the shortfall in energy may be met by catabolism of body proteins, which results in increased urea concentrations in the blood (Greenwood et al., 2002). The overall mean urea concentration was $6.38 \mathrm{mmol} / \mathrm{L}$ and it was within the normal range of 3.6 to $8.9 \mathrm{mmol} / \mathrm{L}$ reported for cows (Merck Veterinary Manual, 2010). The general decrease in urea concentrations in the cows from week I to week 13 in the three groups may be ascribed to an improvement in the nutritional status of the cows, evidenced by an increased BCS as lactation progressed. This may have improved their energy balance status, reducing the mobilization of body protein reserves.

Early cycling cows recorded higher plasma concentrations of creatinine than the late cycling cows. The concentration of creatinine in the blood has been directly related to muscle mass, as it is a product of muscle metabolism and, as a result, is significantly correlated to live weight (Whittet et al., 2004). As creatinine excretion is influenced by muscle mass, the early cycling cows with higher body weight $(298.8 \mathrm{~kg})$ excreted more creatinine than the late cycling cows with lower body weight ( $283.5 \mathrm{~kg}$; Table 1$)$. The overall mean creatinine value of $97.8 \mathrm{mmol} / \mathrm{L}$ obtained in this study was within the normal range of $44-194 \mathrm{mmol} / \mathrm{L}$ reported for cows (Merck Veterinary Manual, 2010). Creatinine concentrations in the plasma remained relatively higher and stable from week 1 to week 9 postpartum in the early cycling cows. The concentrations tended to decline from week 1 to week 11 postpartum in the non-cycling cows which is an indication of prolonged active tissue protein catabolism in these cows, suppressing the resumption of ovarian activity. For the late-cycling cows the protein catabolism may be less as indicated by a steady increase in the levels from week 1 to 9 postpartum, before stabilizing at a level higher than in the non-cycling cows.

\section{Conclusion}

Cows with higher plasma concentrations of urea and lower creatinine concentrations were at a risk of delayed resumption of ovarian cyclicity. This indicates poor nutritional status especially an energy deficiency of cows in the production system.

\section{Acknowledgements}

Mama Abdulai and Afranie are thanked for their assistance with blood sampling. Special thanks to Tagoe of the Biochemistry Department and Ofori of the Central Laboratory of the Korle-Bu Teaching Hospital for determination of progesterone and blood metabolites.

\section{References}

Agenas, S., Heath, M.F., Nixon, R.M., Wilkinson, J.M. \& Phillips, C.C., 2006. Indicators of under nutrition in cattle. Anim. Welf. 15, 149-160.

Ahmad. I., Lodhi, L.A., Qureshi, Z.I. \& Younis, M., 2004. Studies on blood glucose, total protein, urea and cholesterol levels in cyclic, non-cyclic and endometritic crossbred cows. Pak. Vet. J. 24, 92-94.

Allain, C.C., Poon, L.S., Chan, C.S.G., Richmond, W. \& Fu, P.C., 1974. Enzymatic determination of total serum cholesterol. Clin. Chem. 20, 470-475.

Ambrose, R.T., Ketchum, D.F. \& Smith, J.W., 1983. Creatinine determined by "High Performance" Liquid Chromatography. Clin. Chem. 29, 256-259.

Boonprong, S., Sribhen, C., Choothesa, A., Parvizi, N. \& Vajrabukka, C. 2007. Blood biochemical profiles of Thai indigenous and Simmental x Brahman crossbred cattle in the Central Thailand. J. Vet. Med. A 54, 62-65.

Ciccioli, N.H., Wettemann, R.P., Spicer, L.J., Lents, C.A., White, F.J. \& Keisler, D.H., 2003. Influence of body condition at calving and postpartum nutrition on endocrine function and reproductive performance of primiparous beef cows. J. Anim. Sci. 81, 3107-3120.

Coppo, J.A., 2004. Biochemistry demonstration of malnutrion state in early weaned half-bred Zebu calves. Rev. de Invest. Agropecuarias 33, 81-100.

Diskin, M.G., Mackey, D.R., Roche, J.F. \& Sreenan, J.M., 2003. Effects of nutrition and metabolic status on circulating hormones and ovarian follicle development in cattle. Anim. Reprod. Sci. 78, 345-370.

Doumas, B.T. \& Biggs, H.G., 1972. Determination of serum albumin. Stand. Meth. Clin. Chem. 7, 175-188. 
Doumas, B., Bayse, D.D., Carter, R.J., Peters, T. \& Schafer, R., 1981. A candidate reference method for determination of total protein in serum: 1. Development and validation. Clin. Chem. 27, 1642.

Greenwood, P.L., Hunt, A.S., Slepetis, R.M., Finnerty, K.D., Alston, C., Beermann, D.H. \& Bell, A.W., 2002. Effects of birth weight and postnatal nutrition on neonatal sheep. III. Regulation of energy metabolism. J. Anim. Sci. 80, 2850-2861.

Hess, B.W., Lake, S.L., Scholljegerdes, E.J., Weston, T.R., Nayigihugu, V., Molle, J.D.C. \& Moss, G.E., 2005. Nutritional controls of beef cow reproduction. J. Anim. Sci. 83, E90-E106.

Kaneko, J.J., Harvey, J.W. \& Bruss, M.L., 1997. Clinical Biochemistry of Domestic Animals (5 ${ }^{\text {th }}$ ed.). Academic Press, Inc., New York, USA.

Kapele, P.M., Japtap, D.G., Badukale, D.M. \& Sahatpure, S.K., 2008. Serum total proteins and serum total cholesterol levels in Gaolao cattle. Vet. Wrld 1 (4), 115-116.

Kohn, R.A., Dinneen, M.M. \& Russek-Cohen. E., 2005. Using blood urea nitrogen to predict nitrogen excretion and efficiency of nitrogen utilization in cattle, sheep, goats, horses, pigs, and rats. J. Anim. Sci. 83, 879-889.

Lindsay, D.B., Hunter, R.A., Gazzola, C., Spiers, W.G. \& Sillence, M.N., 1993. Energy and growth. Aust. J. Agric. Res. 44, 875-889.

Maciel, S.M., Chamberlain, C.S., Wettemann, R.P. \& Spicer, L.J., 2001. Dexamethasone influences endocrine and ovarian function in dairy cattle. J. Dairy Sci. 84, 1998-2009.

Mapekula, M., Mapiye, C. \& Chimonyo, M., 2011. Changes in metabolites concentration in Nguni and crossbred calves on natural pasture. Asian-Aust. J. Anim. Sci. 24 (11), 1569-1576.

Mapiye, C., Chimonyo, M., Dzama, K. \& Marufu, M.C., 2010. Protein status of indigenous Nguni and crossbred cattle in the semi-arid communal rangelands in South Africa. Asian-Aust. J. Anim. Sci. 23 (2), 213-225.

Merck Veterinary Manual, 2010. A handbook of diagnosis, therapy, and disease prevention and control for the veterinarian. $\left(10^{\text {th }}\right.$ ed.) Eds: Kahn, C.M. \& Line, S., Merck and Co. Inc., New Jersey, U.S.A. pp. 905-908.

Montiel, F. \& Ahuja, C., 2005. Body condition and suckling as factors influencing the duration of postpartum anestrus in cattle: A review. Anim. Reprod. Sci. 85, 1-26.

Murphy, J.J., 1999. The effects of increasing the proportion of molasses in the diet of milking cows on milk production and composition. Anim. Feed Sci. Technol. 79, 189-198.

Ndlovu, T., Chimonyo, M., Okoh, A.I., Muchenje, V., Dzama, K. \& Raats, J.G., 2007. Review: Assessing the nutritional status of beef cattle: current practices and future prospects. Afr. J. Biotech. 6 (24), 2727-2734.

Nicholson, M.J. \& Butterworth, M.H., 1986. A guide to condition scoring of Zebu cattle. International Livestock Centre for Africa, Addis Ababa. 29 pp.

Obese, F.Y., Okantah, S.A., Oddoye, E.O.K. \& Gyawu, P., 1999. Post-partum reproductive performance of Sanga cattle in small-holder peri-urban dairy herds in the Accra plains of Ghana. Trop. Anim. Hlth. Prod. 31, 181-190.

Obese, F.Y., Dafour-Oduro, K.A., Gomda, Y. \& Bekoe, E., 2010. Reproductive performance following artificial insemination in Sanga and Crossbred (Friesian $\times$ Sanga) cows in the Accra Plains of Ghana. In: Sustainable Improvement of Animal Production and Health. Eds: Odongo, N.E., Garcia, M. \& Viljoen, G.J., IAEA Publication, Vienna, Austria. pp. 201-203.

Okantah, S.A., Obese, F.Y., Oddoye, E.O.K., Gyawu, P. \& Asante, Y., 1999. A survey on livestock and milk production characteristics of peri-urban agropastoral dairying in Ghana. Gh. J. Agric. Sci. 32, 39-46.

Otto, F., Baggasse, P., Bogin, E., Harun, M. \& Vilela, F., 2000. Biochemical blood profile of Angoni cattle in Mozambique. Israel J. Vet. Med. 55, 1-9.

Pambu-Gollah, R., Cronje, P.B. \& Casey, N.H., 2000. An evaluation of the use of blood metabolite concentrations as indicators of nutritional status in free-ranging indigenous goats. S. Afr. J. Anim. Sci. 30, 115-120.

Reist, M., Koller, A., Busato, A., Kupfer, U. \& Blum, J.W., 2000. First ovulation and ketone body status in the early postpartum period of dairy cows. Theriogenology $54,685-701$.

Saleh, N., Mahmud, E. \& Waded, E., 2011. Interactions between insulin like growth factor 1, thyroid hormones and blood energy metabolites in cattle with postpartum inactive ovaries. Nat. Sci. 9 (5), 56-63.

Samadi, F., Phillips, N.J., Blache, D., Martin, G.B. \& D'Occhio, M.J., 2013. Interrelationships of nutrition, metabolic hormones and resumption of ovulation in multiparous suckled beef cows on subtropical pastures. Anim. Reprod. Sci. 137, 137-144. 
Sampson, E.J., Baird, M.A., Burtis, C.A., Smith, E.M., Witte, D.L. \& Bayse, D.D., 1980. Coupled-enzyme equilibrium method for measuring urea in serum: optimization and evaluation of the AACC study group on urea candidate reference method. Clin. Chem. 26, 816-826.

SAS, 1999. Statistical Analysis System Version 8 for windows. SAS Institute Inc., Cary, North Carolina, USA.

Shrestha, H.K., Nakao, T., Suzuki, T., Akita, M. \& Higaki, T., 2005. Relationships between body condition score, body weight, and some nutritional parameters in plasma and resumption of ovarian cyclicity postpartum during pre-service period in high-producing dairy cows in a subtropical region in Japan. Theriogenology 64, 855-866.

Stockham, S.L. \& Scott, M.A. 2002. Fundamentals of Veterinary Clinical Pathology. lowa State University Press, Ames. I.A., USA.

Tamadon, A., Kafi, M., Saeb, M., Mirzaei, A. \& Saeb, S., 2011. Relationships between insulin-like growth factor-I, milk yield, body condition score, and postpartum luteal activity in high-producing dairy cows. Trop. Anim. Hlth. Prod. 43, 29-34.

Trinder, P., 1969. Determination of glucose in blood using glucose oxidase with an alternative oxygen receptor. Ann. Clin. Biochem. 6, 24.

Walters, A.H., Pryor, A.W., Bailey, T.L., Pearson, R.E. \& Gwazdauskas, F.C., 2002. Milk, yield, energy balance, hormone, follicular and oocytes measures in early and mid-lactation Holstein cows. Theriogenology 57, 949-961.

Wettemann, R.P., Lents, C.A., Ciccioli, N.H., White, F.J. \& Rubio, I., 2003. Nutritional- and suckling-mediated anovulation in beef cows. J. Anim. Sci. 81 (E. Supplement 2), E48-E59.

Whitaker, D.A., Goodger, W.J., Garcia, M., Perera, B.M.A.O. \& Wittwer, F., 1999. Use of metabolite profiles in dairy cattle in tropical and subtropical countries on smallholder dairy farms. Prev. Vet. Med. 38, 119-131.

Whittet, K.M., Klopfenstein, T.J., Erickson, G.E., Loy, T.W. \& McDonald, R.A., 2004. Effect of age, pregnancy, and diet on urinary creatinine excretion in heifers and cows. Nebraska Beef Cattle Report. No. 212. www. digitalcommons.unl.edu/animalscinbcr/212. Accessed on $27^{\text {th }}$ Dec., 2013. 